\title{
CARDIAC SYMPATHETIC MODULATION INCREASE AFTER WEIGHT LOSS IN COMBAT SPORTS ATHLETES
}

\author{
AUMENTO DA MODULAÇÃO CARDÍACA SIMPÁTICA DEPOIS DE PERDA PONDERAL EM ATLETAS \\ DE COMBATE
}

Original Article

ARTIGO ORIGINAL

Artículo Original

\author{
AUMENTO DE LA MODULACIÓN CARDÍACA SIMPÁTICADESPUÉS DE LA PÉRDIDA PONDERAL \\ ENATLETAS DE COMBATE
}

\begin{abstract}
Bruno do Nascimento-Carvalho' (Physical Education Professional)

Miguel Angel Condori Mayta' ${ }^{1}$ (Physical Education Professional)

João Eduardo Izaias

(Physical Education Undergraduate)

Marcio Roberto Doro'

(Physical Education Professional)

Katia Scapini'

(Physiotherapist)

Erico Caperuto'

(Physical Education Professional)

Juliana Valente Francica Grilletti ${ }^{1}$

(Physiotherapist)

Iris Callado Sanches ${ }^{1}$

(Physical Education Professional)
\end{abstract}

1. São Judas Tadeu University, Human Movement Laboratory, São Paulo, SP, Brazil.

\section{Correspondence:}

Iris Callado Sanches. Universidade São Judas Tadeu. Rua Taquari, 546, São Paulo/SP, Brazil. 03166-000. proficsanches@usjt.br

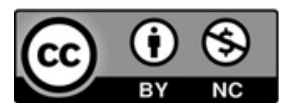

\begin{abstract}
Introduction: Although the rapid weight loss process is undertaken by combat sports athletes very often, the impact of this practice on cardiovascular health is not fully understood. Objective: To verify the effects of the rapid weight loss process undertaken by combat sports athletes on hemodynamic parameters, cardiovascular autonomic modulation and mood state. Methods: Eight male fighters $(21.62 \pm 1.49$ years, $71.25 \pm 3.54 \mathrm{~kg}$, $1.74 \pm 0.03 \mathrm{~cm}$ ) were assessed in the city of São Paulo. The subjects had $5.37 \pm 0.77$ years of practice and were training $5.75 \pm 0.45$ days per week, for $3.05 \pm 0.69$ hours per day. The athletes were assessed on 2 occasions: 14 days before and 1 day before official weigh-in. Weight, height and bioimpedance were used for body composition analysis. Mood state was assessed using the Brums Mood Scale. Blood pressure was measured at rest with a digital meter. Cardiovascular autonomic modulation was obtained through an analysis of heart rate variability recorded for 25 minutes at rest. The Student's t-test for dependent samples was used for comparison between time points. Values of $p<0.05$ were considered significant. Results: No differences in body composition were observed between the time points evaluated. After the weight loss strategy, increases in mood state parameters related to anger, vigor and fatigue categories were observed. Blood pressure did not change between the time points evaluated. However, an increase in heart rate associated with greater sympathetic modulation was observed after the weight loss strategy. There were no differences in autonomic modulation parameters representing parasympathetic activity. Conclusions: The study provided evidence of a higher cardiovascular risk in athletes as a result of this rapid weight loss practice, which is very concerning since combat sports athletes repeat this process several times during their lives. Level of Evidence IV; Study type: Case series.
\end{abstract}

Keywords: Weight loss; Sympathetic nervous system; Martial arts.

\section{RESUMO}

Introdução: Apesar de o processo de perda ponderal rápida ser realizado por atletas de esporte de combate com muita frequência, os impactos dessa prática sobre a saúde cardiovascular não estão totalmente esclarecidos. Objetivo: Verificar os efeitos do processo de perda ponderal rápida realizado pelos atletas de esportes de combate sobre parâmetros hemodinâmicos, modulação autonômica cardiovascular eestado de humor. Métodos: Foram avaliados oito lutadores do sexo masculino $(21,62 \pm 1,49$ anos, $71,25 \pm 3,54 \mathrm{~kg}, 1,74 \pm 0,03 \mathrm{~cm})$ na cidade de São Paulo. Os sujeitos tinham 5,37 $\pm 0,77$ anos de prática, treinavam 5,75 $\pm 0,45$ dias por semana, durante 3,05 $\pm 0,69$ horas por dia. Os atletas foram avaliados em duas oportunidades: 14 dias e 1 dia antes da pesagem. Foram realizadas avaliações de massa corporal, altura e bioimpedância para análise da composição corporal. O estado de humor foi avaliado pela da escala de humor de Brums. A pressão arterial foi aferida em repouso com medidor digital. A modulação autonômica cardiovascular foi obtida pela análise de variabilidade da frequência cardíaca gravada durante 25 minutos em repouso. Para a comparação entre os momentos, foi utilizado testet de Student para amostras dependentes. Os valores dep $<0,05$ foram considerados significativos. Resultados: Não foram observadas diferenças na composição corporal entre os momentos avaliados. Após a estratégia de perda ponderal, foram observados aumentos dos parâmetros de humor relacionados às categorias raiva, vigor e fadiga. A pressão arterial não se alterou entre os momentos avaliados. Entretanto, verificou-se aumento da frequência cardíaca associado à maior modulação simpática após a estratégia de perda ponderal. Os parâmetros de modulação autonômica representativos de atividade parassimpática não apresentaram diferenças. Conclusões: Houve maior risco cardiovascular nos atletas em decorrência dessa prática de perda ponderal rápida, o que é muito preocupante, tendo em vista que os atletas de esportes de combate repetem esse processo várias vezes durante a vida. Nível de Evidência IV; Tipo de estudo: Série de casos.

Descritores: Perda de peso; Sistema nervoso simpático; Artes marciais.

\section{RESUMEN}

Introducción: A pesar de que el proceso de pérdida ponderal rápida sea realizado por atletas de deporte de combate con mucha frecuencia, los impactos de esta práctica sobre la salud cardiovascular no están totalmente aclarados. Objetivo: Verificar los efectos del proceso de pérdida ponderal rápida realizado por los atletas de deportes de combate 
sobre parámetros hemodinámicos, modulación autonómica cardiovasculary el estado de humor. Métodos: Se evaluaron 8 luchadores del sexo masculino $(21,62 \pm 1,49$ años, $71,25 \pm 3,54 \mathrm{~kg}, 1,74 \pm 0,03 \mathrm{~cm})$ en la ciudad de São Paulo.

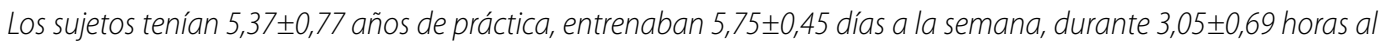
día. Los atletas fueron evaluados en dos oportunidades: 14 días y 1 día antes del pesaje. Se realizaron evaluaciones de masa corporal, altura y bioimpedancia para análisis de la composición corporal. El estado de humor fue evaluado a través de la escala de humor de Brums. La presión arterial se midió en reposo con medidor digital. La modulación autonómica cardiovascular fue obtenida a través del análisis de variabilidad de la frecuencia cardíaca grabada durante 25 minutos en reposo. Para la comparación entre los momentos, se utilizó la prueba t de Student para muestras dependientes. Los valores de $p<0,05$ se consideraron significativos. Resultados: No se observaron diferencias en la composición corporal entre los momentos evaluados. Después de la estrategia de pérdida ponderal, se observaron aumentos en los parámetros de humor relacionados con las categorías rabia, vigor y fatiga. La presión arterial no se alteró entre los momentos evaluados. Sin embargo, se observó un aumento en la frecuencia cardíaca asociado a la mayor modulación simpática después de la estrategia de pérdida ponderal. Los parámetros de modulación autonómica representativos de actividad parasimpática no presentaron diferencias. Conclusiones: Hubo mayor riesgo cardiovascular en los atletas como consecuencia de esta práctica de pérdida ponderal rápida, lo que es muy preocupante, teniendo en cuenta que los atletas de deportes de combate repiten este proceso varias veces durante su vida. Nivel de Evidencia: IV. Tipo de estudio: Serie de casos.

Descriptores: Pérdida de peso; Sistema nervioso simpático; Artes marciales.

\section{INTRODUCTION}

"Combat sports" are considered as competitive forms of fights and martial arts'. The categories in which athletes are divided into competitions are based on body weight. So, before the confrontations, the athletes are submitted to weighing to confirm that they fit the subscribed class. In this way, many competitors decide to adopt the rapid weight loss strategy at the days that precede competition to try to obtain advantages in facing theoretically lighter and weaker opponents ${ }^{2}$.

To achieve this great weight loss in the pre-competition week, the athletes use different methods such as steam room visits, thermic clothes and diets with carbohydrates and liquids restrictions. Some studies suggest that, with time and repetition, these practices cause hormonal, hydroelectrolitic, mood state and mental imbalance, variations in renal and cardiovascular functions and a deficit in the torque capacity ${ }^{2,3}$.

The strategies of weight loss affect the cardiovascular system, provoking decrease of plasmatic volume blood, increase of the heart rate in rest, lower level of blood ejection, resulting in lower capacity to sustain work at a constant rate ${ }^{4,5}$. In this way, the analysis of heart rate variability enables to gauge the autonomic nervous system modulation, under different physiological conditions, and can demonstrate oscillations of intervals between consecutive cardiac pulses, that are related to the influences of autonomic nervous system over the sinus node, being a non-invasive method capable of identifying cardiovascular phenomenon in healthy individuals, athletes and disabled people ${ }^{6}$.

In view of these information, the aim of this study was to verify the effects of the rapid weight loss process used by combat sports athletes under the hemodynamic parameters, cardiovascular autonomic modulation and mood pattern.

\section{MATERIAL AND METHODS}

The non-probabilistic intentional sampling was composed of 8 male combat sports athletes (62.5\% MMA fighters, 25\% Brazilian Jiu-Jitsu fighters and $12.55 \%$ Muay Thai competitors) that were recruited through email invitation, cellphone contact or social media divulgation. The inclusion criteria were to be a practitioner of any combat sports modality at amateur or professional level for at least 1 year and agree to the tests exposed in this study and sign an informed consent form. Athletes that did not follow the previous guidelines for the bio impedance test were excluded.
To achieve the objectives proposed, the combat sports fighters were evaluated at two opportunities, which were 14 days and one day before the weighing. The data were collected with the athletes at the places where their training occurred and taken to analysis at Human Movement Laboratory, in Sao Judas Tadeu University. This study was approved by the Ethics Committee as established by 1.671.569.

For the characterization of the samples utilized in this study, an anamnesis was used to approach practice time, week frequency and training duration, as well as the competition history of each athlete. Moreover, the athletes were instructed to report if they utilized any anabolic steroids, or pharmacological product to help at the rapid weight loss process.

After the application of anamnesis, Brums Mood Scale was applied. Brums Mood Scale contains 24 simple mood indicators, such as anger sensations, disposition, nervousness and dissatisfaction. The subjects rate how they feel in relation to such situations, from 0 (nothing) to 4 (extremely). The question form was filled by the participants. The sensations listed at the scale correspond to categories that point to states: tension, depression, anger, vigor, fatigue and mental confusion.

The body mass index (BMI) was calculated through the measurements of weight and height, according to the following formula:

$$
\text { Body mass index }=\frac{\text { weight }}{(\text { height })^{2}}
$$

The evaluation of the body composition was analyzed through the electric bio impedance method (brand Biodynamics, model BIA450). To accomplish this, the subjects were at supine posture, fasting for 4 hours a $d$ were advised to abstain caffeine, alcohol and physical exercise for at least 24 hours before the procedure. The bio impedance provides percentage for fat mass, lean mass and amount of body fluid through the passage of a low intensity (500 to $800 \mu \mathrm{A}$ ) and high frequency $(50 \mathrm{kHz})$ electric current through the body, being imperceptible and therefore painless.

Then, the arterial pressure was measured 3 times (with a 2 minutes interval between each measure) in rest by a digital arterial pressure meter (brand Omron, model HEM-705CPINT), following the norms of Sociedade Brasileira de Hipertensão.

The recording of $\mathrm{R}-\mathrm{R}$ intervals (IP, $\mathrm{ms}$ ) was done using a frequency meter (brand Polar, model RS800) at the training locations. The recording lasted 25 minutes with the subjects being in rest, and, posteriorly, 
transferred to the Polar Precision Performance Software through the Interface Infrared, or IrDA, that allows the bidirectional trade of data with a microcomputer, to posterior analysis of the variability of the interval of cardiac. After these procedures, the data was transferred and saved in TXT archives, using the software Kubius to analyze the variability of the heart rate both in time and frequency domains (Fast Fourier Transform - FFT).

\section{Statistical analysis}

The results are presented as mean \pm SEM. The data homogeneity was tested through the Kolmogorov-Smirnov test. To compare previous and posterior results of the independent samples, the Student's t test was used. The significance level adopted was $p<0.05$.

\section{RESULTS}

The characteristics of the samples are represented in Table 1. The athletes reported not to use any kind of drugs.

Among these strategies to weight loss used by the athletes, the one that presented higher frequency was the carbohydrate restriction (34\%), followed by lipids (20\%) and liquid restriction (20\%). It's worth noting that, all of the practitioners of the liquid restriction reported the use of diuretic medications. A smaller part of the athletes (13\%) also stated that they raise the training quantity to, consequently, promote a negative energetic balance associated to the liquid loss in form of sweat.

The body weight, BMI, lean mass, fat mass, and total body fluids data are presented in Table 2 .

Table 3 shows the collected data through Brums Mood Scale. After the weight loss strategy, increases were observed in the parameters related to anger, vigor and fatigue.

Table 1. Characterization of the sample of athletes used in this study.

\begin{tabular}{c|c}
\hline Parameters & Characteristics \\
\hline Age (years) & $21.62 \pm 1.49$ \\
\hline Initial body weight $(\mathrm{kg})$ & $71.25 \pm 3.54$ \\
\hline Height $(\mathrm{cm})$ & $174 \pm 003$ \\
\hline Practice time (years) & $5.37 \pm 0.77$ \\
\hline Weekly training frequency (days) & $5.75 \pm 0.45$ \\
\hline Duration of the training session (hours) & $3.05 \pm 0.69$ \\
\hline Historic of competitions & $13.37 \pm 5.78$
\end{tabular}

Data presented as mean \pm SEM

Table 2. Body composition evaluated in athletes 14 days before weighing and 1 day before weighing.

\begin{tabular}{c|c|c|c|c}
\hline Parameters & $\begin{array}{c}\text { 14 days before } \\
\text { weighing }\end{array}$ & $\begin{array}{c}\text { 1 day before } \\
\text { weighing }\end{array}$ & Delta & p \\
\hline Body weight $(\mathrm{kg})$ & $71.25 \pm 3.54$ & $69.33 \pm 4.08$ & $-3.83 \pm 0.42$ & 0.71 \\
\hline Body mass index & $23.37 \pm 0.51$ & $22.45 \pm 0.47$ & $-6.53 \pm 3.47$ & 0.21 \\
\hline Lean mass $(\mathrm{kg})$ & $68.86 \pm 3.83$ & $66.62 \pm 4.45$ & $-3.12 \pm 0.80$ & 0.71 \\
\hline Fat mass $(\mathrm{kg})$ & $5.94 \pm 1.13$ & $5.37 \pm 0.84$ & $-1.12 \pm 0.61$ & 0.70 \\
\hline Total body fluids $(\mathrm{kg})$ & $51.84 \pm 3.51$ & $49.82 \pm 4.06$ & $-2.77 \pm 0.83$ & 0.58 \\
\hline Data presented as mean \pm SEM.
\end{tabular}

Table 3. Brums Mood Scale results in athletes 14 days before weighing and 1 day before weighing.

\begin{tabular}{c|c|c|c|c}
\hline Parameters & $\begin{array}{c}\text { 14 days before } \\
\text { weighing }\end{array}$ & $\begin{array}{c}\text { 1 day before } \\
\text { weighing }\end{array}$ & Delta & p \\
\hline Tension & $6.50 \pm 1.22$ & $6.83 \pm 1.60$ & $1.00 \pm 0.36$ & $>0.99$ \\
\hline Depression & $2.12 \pm 0.81$ & $3.83 \pm 1.62$ & $2.00 \pm 1.18$ & 0.46 \\
\hline Anger & $5.50 \pm 1.42$ & $11.33 \pm 1.89^{*}$ & $6.50 \pm 1.23$ & 0.01 \\
\hline Vigor & $11.25 \pm 1.27$ & $7.16 \pm 1.77^{*}$ & $-5.66 \pm 2.04$ & 0.02 \\
\hline Confusion & $1.75 \pm 0.70$ & $3.66 \pm 1.22$ & $2.16 \pm 0.83$ & 0.17 \\
\hline Fatigue & $5.37 \pm 1.51$ & $11.83 \pm 2.05^{*}$ & $7.66 \pm 2.33$ & 0.02 \\
\hline Data presented as mean \pm SEM. * $\mathrm{p}<0.05$ vs. 14 days before weighing.
\end{tabular}

The hemodynamic evaluations are showed in Table 4. There were not any differences in arterial pressure. However, the heart rate was higher after the weight loss strategy than at the first measurements.

The analysis of the cardiovascular autonomic modulation at the time domain provided the following parameters: standard deviation of the R-R interval (SD-RR), mean of square root of the differences between heartbeats (RMSSD), percentage of the total number of heartbeats in 50 milliseconds (pNN50). For interpretation purposes, these parameters are related to the cardiac parasympathetic modulation, which indicates cardiovascular protection for the individual. No differences were observed after the weight loss strategy (Table 4).

In relation to the analysis of the cardiovascular autonomic modulation at the frequency domain, the following parameters were observed: low frequency band of pulse interval (LF-PI), high frequency band (HF-PI), relation between the LF-PI and HF-PI bands (LF/HF). For interpretation purposes, the LF-PI band is considered to be related to sympathetic modulation, HF-PI band is related to parasympathetic modulation and the relation LF/HF represents the sympatho-vagal balance.

The results demonstrated an increase in cardiac sympathetic modulation (LF-PI) after the weight loss process, evidencing higher cardiovascular risk in these athletes. No differences were observed in the parasympathetic modulation (HF-PI) and sympatho-vagal balance (LF/ HF) (Table 4).

Table 4. Hemodynamic parameters and cardiovascular autonomic modulation assessed in athletes 14 days before weighing and 1 day before weighing.

\begin{tabular}{|c|c|c|c|}
\hline Parameters & $\begin{array}{c}14 \text { days before } \\
\text { weighing }\end{array}$ & $\begin{array}{l}1 \text { day before } \\
\text { weighing }\end{array}$ & $p$ \\
\hline $\begin{array}{c}\text { Systolic arterial } \\
\text { pressure }(\mathrm{mmHg})\end{array}$ & $126.18 \pm 2.65$ & $127.00 \pm 3.00$ & 0.79 \\
\hline $\begin{array}{c}\text { Diastolic arterial } \\
\text { pressure }(\mathrm{mmHg})\end{array}$ & $69.81 \pm 1.96$ & $70.91 \pm 2.31$ & 0.72 \\
\hline Heart rate (bpm) & $54.91 \pm 2.54$ & $65.43 \pm 3.40 *$ & 0.01 \\
\hline SD-RR (ms) & $79.49 \pm 10.14$ & $77.43 \pm 8.82$ & 0.88 \\
\hline RMSSD (ms) & $77.81 \pm 35.05$ & $72.56 \pm 11.24$ & 0.65 \\
\hline pNN50 (ms) & $46.38 \pm 6.82$ & $38.67 \pm 8.12$ & 0.47 \\
\hline LF-PI (\%) & $1312 \pm 333$ & $2841 \pm 470$ * & 0.01 \\
\hline HF-PI (\%) & $2785 \pm 393$ & $2067 \pm 280$ & 0.15 \\
\hline LF/HF & $0.94 \pm 0.13$ & $1.10 \pm 0.03$ & 0.24 \\
\hline
\end{tabular}

\section{DISCUSSION}

To accomplish the proposed objectives, anthropometric and hemodynamic parameters and mood state were compared 14 days vs. 1 day in combat sports athletes before weighting. The most relevant result of this study was the increase of the heart rate after the rapid weight loss strategy, associated to a higher cardiac sympathetic modulation. Such findings evidence a higher cardiovascular risk in athletes as a result of this practice, which is very concerning in view of the repetition of this process during their competitive lives.

Furthermore, the mood state of the athletes modified in comparison to the 14 days before weighting. The emotional factors inherent to the approach of the competition certainly interfere at the interpretation of these results. However, the discomfort resulted from the restriction of carbohydrates, lipids and liquids during the days that preceded this evaluation cannot be discarded.

The methods to rapid weight loss related by the athletes were diets with the restriction of carbohydrates (34\%), lipids (20\%) and liquid (20\%), and higher training volume (13\%). In another study, the authors report that among the methods used to decrease weight, the athletes used steam rooms/thermic clothes (90\%), restriction of 
carbohydrates (80\%) and liquids (40\%) ${ }^{7}$. In the present study, different from the articles found, the athletes claimed to increase the training volume as a strategy to rapid weight loss. Indeed, the increase of training can potentiate the negative energetic balance, associated to the carbohydrate and lipids restriction, as well as promote higher water loss, through transpiration.

A variable that also must be taken in account is the frequency that the athletes submit to the rapid weight loss process. Some studies indicate that the "win-lose" weight cycle is called weight cycling, and those who practice it have a lower rate of basal metabolism. It is possible that, because of this habit, the athletes that perform it have a greater difficulty in maintaining weight(2). Another consequence of this is also great hormonal and cognitive alterations, besides provoking a series of alterations in growth and development of the teenagers.

The weight loss was already studied and considered negative in some studies due to its potential malign effects over health and performan$\mathrm{ce}^{2}$. There are still innumerous physiologic and psychologic alterations caused by such process, considering that, in elite sports, a minimum loss at performance can be crucial at a combat decision ${ }^{5}$.

The loss of body liquids (dehydration) can cause a series of alterations on body functioning that range from alteration of the hydroelectric equilibrium, to difficulty in thermoregulatory action, to even health risk, disturbing the sportive performance . $^{8}$

Other risk factors associated to the absence of water and electrolytes replenishment are torque loss, cramps and hypernatremia 9 . There are studies that evidence alterations at intra and extracellular volume, that indicate great alterations in body functions, affecting the cardiovascular, excretory, endocrine and nervous systems, thermoregulation and metabolism, being able to harm physical and psychological capacities during exercise ${ }^{10}$.

One of the variables related to the decrease of weight in the pre-competitive period are matters related to state of mood, because in competitive sports the elevated stress triggers various other imbalances that range from physiological and biomechanical variations to the psychological ones that can provenly interfere at the result expected by the athletes ${ }^{3}$.

At the current study, the mood state of the athletes in the categories of anger, vigor and fatigue was altered in comparison to the responses 14 days before weighting. The emotional factors inherent to the proximity with the competition certainly interfere at the interpretation of these results. However, the discomfort because of the restriction of carbohydrates, lipids and liquids during the days that preceded this evaluation cannot be discarded.

In another quantitative research realized with Olympic athletes, $60 \%$ of them cited that they felt nervous because of the rapid weight loss before the competition, $45 \%$ claimed that also felt tired, 35\% felt weak, $32,5 \%$ felt irritated and exhausted and only $30 \%$ of the participants reported to feel normal with the weight loss ${ }^{11}$.

A study with boxers described that after the weight loss (at burpee test), the conscience of movements got distorted, with the sensation of diminution of physical vigor and, consequently, with the athletes not reaching the stipulated goal on the proposed test ${ }^{5}$. Another study realized with judokas that utilized the Profile of Mood States (POMS), after 7 days of alimentary restriction, had as result an increase of the states of confusion, anger, fatigue, tension and lower vigor ${ }^{2}$.

Regarding cardiovascular system, if only the martial arts practice were considerate without the weight loss process, it could be defined as beneficial to factors such as arterial pressure and other cardiovascular replies, because presents at the post-exercise recovery period a reduction of systolic arterial pressure (SAP) and heart rate ${ }^{12}$.
However, there are authors that describe that the dehydration that occurs at the weight loss process affects negatively the cardiovascular system ${ }^{4}$. There are still authors that define that the alterations caused by the hypo hydration are: decrease in blood volume, cardiac yield, thermoregulation and arterial pressure ${ }^{5}$. Though, at the current study, there were neither differences in systolic and diastolic arterial pressure after the weight loss process.

The American College of Sports Medicine (ACSM) demonstrated modifications resulting from the rapid weight loss in ergometric tests, which included the diminution of plasmatic blood volume, increase of the heart rate and decrease of the blood ejection volume, causing lower capacity to sustain work at a constant rate ${ }^{4}$.

A study showed a series of physiological changes when the weight loss occurs in a week, such as: lower efficiency of the myocardium, of the maximum consumption of oxygen and damage to the thermoregulatory process $^{13}$. Such alterations indicate that there is an increase in the heart rate, to compensate the diminution of the cardiac output ${ }^{14}$.

Considering the importance of the autonomic modulation at the control of the heart rate, and that precocious alterations on these parameters can precede the appearance of cardiovascular disorders, the autonomic cardiovascular modulation was evaluated ${ }^{15}$. One of the forms very utilized to evaluate the autonomic modulation is through an analysis of the variability of the heart rate.

The variability of the heart rate can be analyzed in the time and frequency domains. At the current study, no differences were observed at the variables analyzed at the time domain. However, at the domain of frequency, the LF band was larger after the rapid weight loss. It's worth noting that the interval between the two evaluations was of only two weeks, that is, in such a short period, due to the changes at the hydric and alimentary ingestion, as well as the training volume, harmful alterations at the autonomic cardiovascular modulation were already observed, evidenced by the increase of sympathetic modulation in these athletes.

The plasmatic hyper osmolality caused by the dehydration can be pointed as a cause for the increase of sympathetic activity in dehydrated people. Thus, the hydric state, along with the body temperature of the individual, can affect the autonomic control over the heart rate ${ }^{16}$.

\section{CONCLUSIONS}

The most important result of this study was the increase of the heart rate after the rapid weight loss strategy, associated to a higher sympathetic modulation in the athletes evaluated. Moreover, the mood state of the athletes was negatively affected after the weight loss. Such findings evidence a higher cardiovascular risk at practitioners of this process, which is very concerning in view of the common repetition during competitive life.

More conclusive results can be obtained by establishing more rigid criteria for inclusion, higher athletes' sample number, focusing in professional athletes, or selecting the samples by combat modality and/or category. Also, amplify the analysis tools of body composition, associating bio impedance to the skinfolds evaluations, can offer more solid indications with respect to the body modifications in athletes at the rapid weight loss process.

\section{ACKNOWLEDGEMENTS}

The authors acknowledge the collaboration of Diana Madureira Santos and Jeferson Santana for the invaluable contribution with respect to the operation of the frequency meter, as well as the software for the analysis of the cardiovascular autonomic modulation.

All authors declare no potential conflict of interest related to this article. 
AUTHORS' CONTRIBUTIONS: BNC (0000-0002-0283-7432)*: conception and design of the research, conducted experiments, analyzed data, interpreted results of experiments, drafted the manuscript, edited and revised the manuscript; MACM (0000-0002-6811-4173)*: conception and design of the research, conducted experiments, drafted the manuscript; JEl (0000-0002-3312-489X)*: prepared figures, edited and revised the manuscript; MRD (0000-0002-4515-5570)*: edited and revised the manuscript; KS (0000-0003-4935-3221)*: edited and revised the manuscript; EC (0000-0001-7766-7506)*: edited and revised the manuscript; JVG (0000-0003-4408-2952)*: conception and design of the research, drafted the manuscript; ICS (0000-0001-6195-4340)*: conception and design of the research, conducted experiments, analyzed data, interpreted results of experiments, prepared figures, drafted the manuscript, edited and revised the manuscript. *ORCID (Open Researcher and Contributor ID).

\section{REFERENCES}

1. Franchini E, Del Vecchio FB. Studies in combat sports: state of the art. Rev Bras Educ Física e Esporte. 2011;25(SPE):67-81.

2. Artioli GG. Perda de peso em esportes de combate de dominio: Revisão e recomendações aplicadas. Rev Bras Cineantropometria e Desempenho Hum. 2006;8(2):92-101.

3. Rocha CA. Humor e estresse de judocas em treinamento e competiçao. Universidade do Estado de Santa Catarina; 2010.

4. Oppliger RA, Case HS, Horswill CA, Landry GL, Shelter AC. American College of Sports Medicine position stand. Weight loss in wrestlers. Med Sci Sports Exerc. 1996 Jun;28(6):ix-xii.

5. Lorenço-Lima L De, Hirabara S. Efeitos da perda rápida de peso em atletas de combate. Rev Bras Ciências do Esporte. 2013;35(1):245-60.

6. Vanderlei LCM, Pastre CM, Hoshi RA, Carvalho TD de, Godoy MF de. Noções básicas de variabilidade da frequência cardíaca e sua aplicabilidade clínica. Brazilian J Cardiovasc Surg. 2009;24(2):205-17.

7. Silva JM dos SO, Gagliardo LC. Análise sobre os métodos e estratégias de perda de peso em atletas de mixed martial arts (M.M.A.) em período pré-competitivo. Rev Bras Nutr Esportiva. 2014;8(43):74-80.

8. Machado-Moreira CA, Vimieiro-Gomes AC, Silami-Garcia E, Rodrigues LOC. Hidratação durante o exercício: A sede é suficiente? Rev Bras Med do Esporte. 2006;12(6):405-9.
9. Loiola PC, Benetti MV, Durante JG, Frade RE, Viebig RF. Perda hídrica e taxa de sudorese após o treino de Muay Thai e Jiu-Jitsu em uma academia de São Paulo. Rev Bras Nutr Esportiva. 2016;10(59):562-7.

10. Faro HKC. Estratégias de perda de peso em lutadores: uma revisão de literatura. Rev Carioca Educ Fís, Rio Janeiro. 2015;10:108-14.

11. Abreu ES de, Nascimento J de F, Santos ALB, Sales CDV, Ferreira HS. Estratégias para perda de peso no periodo pré-competitivo e suas repercussões em atletas de luta olímpica. Rev Bras Nutr Esportiva. 2015;9(50):137-43.

12. Prado ÉJ, Lopes MC de A. Resposta aguda da frequência cardiáca e da pressão arterial em esportes de luta (Jiu Jitsu). Rev Bras Ciências da Saúde. 2009;7(22):63-7.

13. Fabrini SP, Brito CJ, Mendes EL, Sabarense CM, Marins JCB, Franchini E. Práticas de redução de massa corporal em judocas nos períodos pré-competitivos. Rev Bras Educ Física e Esporte. 2010;24(2):165-77.

14. Lelis JRM. A eficácia de uma recuperação alimentar entre a pesagem e o início dos combates em judocas veteranos com perda rápida e moderada de peso. Universidade de Coimbra; 2013.

15. Francica JV. Ajustes cardiovasculares induzidos pelos exercícios resistidos em jovens com história familiar positiva de hipertensão. Universidade São Judas Tadeu; 2008.

16. Pedral RDL, Silva FS, Vila M, Jesus N De. Recuperação autonômica cardíaca pós- exercíco com e sem hidratação. Ciências Biológicas e Saúde Unit. 2016;3:49-66. 